\title{
Australia's Engagement in the South China Sea under the Prospect Theory Approach and Implications for Australia-Vietnam Relations
}

\author{
Huynh Tam Sang ${ }^{1}$ \\ ${ }^{1}$ Faculty of History, Thu Dau Mot University, Vietnam \\ Correspondence: Huynh Tam Sang, Faculty of History, Thu Dau Mot University, Vietnam. Tel: 84-974-433-209. \\ E-mail: huynhtamsang@gmail.com
}

Received: June 8, 2016

Accepted: June 26, 2017

Online Published: July 25, 2017

doi:10.5539/ach.v9n2p60

URL: https://doi.org/10.5539/ach.v9n2p60

\begin{abstract}
Prospect theory, first described in a 1979 paper by Daniel Kahneman and Amos Tversky, proves to be an effective tool to explain how people evaluate risk and make decisions in experimental settings. Due to remarkable insights for social sciences, prospect theory has gone beyond economics and provided insights for international relations. This paper aims at using prospect theory to illuminate the nature of Australia's engagement in the South China Sea (SCS) and thereby clarify the essence of Australia-Vietnam cooperation. In terms of prospect theory approach, the author argues that there are three factors specifying Australia's involvement in the SCS, including: (i) the rise of China in the SCS, (ii) Australia's significant interests in the SCS, and (iii) Australia's proactive middle-power status. In light of certain common interests in the SCS, Australia and Vietnam have been sharing serious concerns about security and the risk of conflict in the SCS. From the year 2009 until now, both countries have actively enhanced diplomatic, political and military ties. Regarding Australia's status and strategic interests in the SCS, the author asserts that Australia should make the SCS more secure by promoting contributions to accommodate its status in the Asia-Pacific region. The findings of this paper would provide helpful guidance for policymakers and leaders from Australia and Vietnam for a better understanding of the increasingly complicated security environment and how to (re-) create a more stable environment in this region.
\end{abstract}

Keywords: Australia, security, South China Sea, cooperation, prospect theory, Vietnam.

\section{A Brief Introduction to Prospect Theory}

Prospect theory is a behavioral economic theory focusing on the analysis of decision-making. The original idea of prospect theory was first developed in the early 1980s by Daniel Kahneman and Amos Tversky in the paper "Prospect Theory: An Analysis of Decision under Risk" (1979). Prospect theory helps explain behaviors of decision makers based on potential outcomes of decisions. Kahneman and Tversky sought to challenge the traditional notions of decision making in the field of behavioral economics. Before the advent of prospect theory, expected utility theory had been widely used by classical and neoclassical economists to explain the rational tendency in making economic decisions. For example, when making choices, people are inclined to choose alternative that help them maximize their benefits. In the expected utility framework, economists hold the view that people feel for gain and loss with the same magnitude (Barberis, 2013). The work of Daniel Kahneman and Amos Tversky proposed that people are more likely to suffer from cognitive biases and often do not make rational choices. In other words, they explored that people are more likely to violate the rules of rational choice when conducting behavioral choices. The two psychologists challenged fundamental assumptions about rational behavioral choice and suggested that psychological and emotional factors play a dominant role in decision-making mechanism. In consequence, the final decision may be not optimal.

Based on such psychological findings, Kahneman and Tversky offered a major turning point in promoting the assumption of risk aversion. Given the probability of achieving a certain benefit, people tend to be risk-averse in the domain of gains but would express a preference for risk-seeking in the domain of losses. Indeed, risk seeking in losses is directly proportional to the probabilities of loss (Tversky, Choices, Values, and Frames, 1984). Consider, for example, when facing with two choices: either to receive the amount of $\$ 1000$; or enter in a lottery (a 50/50 proposition) with 50\% chance of winning and receive $\$ 2,500$ and $50 \%$ chance of losing and receive nothing, the majority of people tend to prefer the first option in terms of risk aversion. Although, in light of the 
expected utility theory, people will be "rational" and prefer the second option because regarding probability calculations, the benefits to be obtained from the second ones outweighs the first (comparing $\$ 1,250$ to $\$ 1000$ ). The risk aversion bears a resemblance to "the sword of Damocles" thus makes people reluctant to accept the potential risks and target for the first option. However, if they must make a decision between the two options of losing $\$ 1000$ or joining a lottery (a 50/50 proposition) with $50 \%$ chance of losing $\$ 2,500$ and $50 \%$ chance of losing nothing, the majority tend to prefer the second option due to the fear of loss. Therefore, the fear of loss can make people engage in risk-seeking behaviors.

Kahneman and Tversky also demonstrated that people are psychologically loss averse after conducting a series of psychological studies. However, because the perceived likelihood of threat or loss is greater than the actual probability of the occurring event, losses will cause more severe psychological consequences than gains though both cases (losses and gains) bring the same value (Daniel Kahneman, 1990). For example, when comparing the case (i) A gained $\$ 20,000$ with (ii) B gained $\$ 50,000$ and then lost $\$ 30,000$, A would be happier than B even though both gained the equivalent profit $(\$ 20,000)$. The psychologists find, for example, that one would deeply regret when having lost $\$ 10$ but would be a little joyful when picking up $\$ 10$. The result of this instance is nearly the same as the earlier ones in which people were extremely obsessed with losses. Due to loss aversion, people "weigh losses more heavily than gains; losses hurt roughly twice as much as gains feel good" (Thaler, 1999).

The findings of Kahneman and Tversky in 1979 provided remarkable insights for economist and thus made a great impression on the study of behavioral economics. From the domain of economics, prospect theory has reached out to social sciences disciplines such as International Relations (IR). With the hope to explain the practice of IR, researchers have studied prospect theory, especially since the early 90 s of the 21 st century. Some political challenging issues were explained using prospect theory approach such as President Roosevelt's decision-making during Munich crisis in mid-September 1938, Carter's April 1980 attempted decision to rescue the American hostages in Iran, and Soviet behavior toward Syria in 1966-67 (Barbara Farnham, 1994). The comprehensive examination of those case studies has proved to be effective in providing helpful guidance for the understanding of decision-making under risk or uncertainty, thus the benefits and pitfalls from prospect theory offer useful dimensions for the analysis of political behavior in terms of both reasoning and practicing.

More radically, prospect theory offers two major arguments, including (Berejekian, 1997):

- In case that maintaining the "status quo" would help in obtaining benefits, between taking the risk with the expectation of obtaining benefits and seeking the "status quo", one would opt for the latter. One prefers the "safe choice" in preference to the uncertain chance of gaining benefits. This typical behavior is the risk-aversion.

- In contrast, when maintaining the "status quo" would not help, between being involved in risk-seeking behaviors in the hope of gaining benefits (although potential losses were not ruled out) and maintaining the "status quo", one would opt for the former. The risky alternative is agreeable as the fear of maintaining the "status quo" could result in the loss of benefits. This attitude toward risk generates risk-seeking behavior.

According to Tversky, under uncertain and risky situations, one's decision depends mainly on beliefs concerning the perceived likelihood of the upcoming events (Tversky, Judgment under Uncertainty: Heuristics and Biases, 1974). In addition, considerations such as ambiguity or vagueness may have great impact on the decision weight. It arrives at the situation in which decision weight under uncertain and risky situations involves "the evaluation of gains and losses and the weighting of uncertain outcomes" (Tversky, Prospect Theory: An Analysis of Decision under Risk, 1979). The following process illustrates the steps for decision-making in the context of perceived security concern of one country. That is: (1) Recognizing that national security is threatened by external factors (at stake) $\rightarrow$ (2) Analyzing and weighing towards gains and losses $\rightarrow$ (3) Making decisions: maintaining the "status quo" or engaging once "the costs of moving away from the status quo are treated as losses and overweighed relative to the benefits (gains) of doing so" (Leonie Huddy, 2013).

Regarding state actors, decision-making has always been associated with strategic calculations. Generally, there are two major types of factors affecting the decision-making of a state, which are internal factors (economic development, pressure from opposition parties, political stability requirement...) and external factors (traditional and non-traditional security threats, the context of globalization and regionalism...). As concern the powerful countries, I argue that those countries can diverge in views and conditioned by external circumstances, of which the prominent factors involve advantages and challenges. In realistic situations, the challenges are the dominant feature. In that sense, studying the factors that contribute to the cognition and decision-making of great powers would provide helpful implications. Besides, great powers are driven by "negative and positive" factors, which state (i) concerns about maintaining power and security and (ii) benefits and opportunities from the regional and international environment and they would embark on risky diplomatic and military interventions in remote 
(far-off) or peripheral regions despite those conflicts pose no direct threat to those great powers. What needs to take into consideration is that those risky interventions may initiate a direct confrontation of rivals in peripheral regions. The perceived losses (i.e., a state's relative power, international status, or prestige) are those factors that encourage great power's involvement in the periphery (Taliaferro, 2004). In such case, leaders of great powers replied heavily on the prospect of losses rather than the prospect of gains. The decision under risk in which great powers are concerned with losses more than comparable gains has vital implications in this case. It could be said that great powers "enjoy a favorable international power position and the perceived benefits of intervention outweigh the costs and risks" (Taliaferro, 2004). In other words, great powers tend to be risk-acceptant with respect to losses when they perceive that their vital interests and political legitimacy are under threat. In this respect, concerns about the prospective loss motivate great powers to adopt risk-acceptant strategies to pursue risky intervention in peripheral conflicts (Levy, 1992).

In the 21st century, contemporary IR have become further complicated and even confusing in some cases. The current state of IR is unrest with increase in international competitions and regional conflicts. Meanwhile, high-probability risk may result in high vulnerability. The high level of uncertainty associated with risk often has major influence on the decision-making process and even distort policymakers' preferences. The complex geostrategic environment of the Asia-Pacific region tends to feature more sensitive to conflict than cooperation due to the lacking of "restraining cooperative structure of regional security" (Brzezinski, 2004) thus makes prospect theory approach increasingly important. In terms of regional security configuration, prospect theory not only challenges the "as if" assumption of rational choice approach (Milton Friedman, 1957) but also deals with "systematic way to explain and predict decisions under risk without prior knowledge about individual preferences" (He, 2014). While great powers are often involved in disputes and conflicts, their risky intervention decisions are well worth studying. Undertaking research on the issue of "what motivates great powers in their decision-making?" would lay a good foundation for figuring out strategic interests and most importantly, identifying and evaluating (potential) threats in conflict regions that can affect the existence and prosperity of great powers.

\section{Australia's Involvement in the South China Sea under the Application of Prospect Theory}

The central question of this paper is: Why does Australia pursue risky intervention strategies in the SCS although the sea is far-off and does not directly threaten the security of Australia's homeland? In terms of prospect theory approach, this paper responds by producing three factors that specify Australia's involvement instead of staying out of SCS conflicts, which include: (i) China's rise in the SCS, (ii) Australia's significant interests in the SCS, and (iii) Australia's proactive middle-power status in the 21st century. China's rise causes concern and poses challenges to Australian foreign policy, thus determines Australia's shift in orientation towards the SCS issue. Australia's significant interests regulate Australia's process for partner choice while Australia's middle-power status has been the driving force for its growing active role in the SCS issue. These three significant factors are not exclusive but mutually reinforcing. Now that Australia's acceptant-risk decision is leaned on the perception that its involvement would bring more gains than losses. In that respect, Australia's refusal to advance presence in the disputed SCS can result in severe setbacks in which political and economic settings along with its international status are included.

\subsection{China's Rise in the South China Sea}

From the end of Second World War (1945) until now, there are five stages that China has been gradually expanding its influence over the SCS with short periods alternating. The critical periods serve as candidates. In 1946-1947, China set foot on some islands within the Paracel and the Spratly Islands. In 1956-1974, China illegitimately occupied Paracel Islands by military forces. In 1988-1995, China occupied some features in the Spratly Islands since 1988 and Mischief Reef since 1995. In 1996-2008, China undertook the so-called policy "maintaining reluctant stability on land but tight control in the sea". In 2009-2013, China engaged in intense territorial disputes in the SCS. A logical process of the China's policy towards the SCS is that when there emerges a "power vacuum" in Southeast Asia (which inherently includes the SCS), China will capitalize on opportunities to fill that vacuum, thus expanding its influence in Southeast Asia (Truong, 2014). Since China officially submitted the U-shaped line (or nine-dotted line) map to the United Nations in 2009, its engagement in the SCS has become increasingly provocative. Consequently, concern about the growth of China's military buildup and territorial squabbling have stoked serve fervor in regional countries.

China's claim to sovereignty over the SCS followed by its escalating tensions have posed a threat to regional security. Given China's quest to be a superpower, it must meet the compulsory requirement: achieving the status of a strong continental power and a great maritime power. Although being widely recognized as a continental 
power, China is still on the way of striving to become a "strong maritime power" (Full text of Hu Jintao's Report at the 18th Party Congress, 2012). In this scenario, attempting to turn the SCS into the so-called "internal lake" is the very first major step in China's determination to dominate the SCS and thus become a strong maritime power. Having learnt from its limitations during the long historical development, China has been pushing a strategy of becoming a great maritime power. Now that the SCS can serve as an important link in PRC's aspirational goal. The ability to control the SCS will provide opportunities for China to promote its strategy in Asia-Pacific. The strong sense of the importance of the SCS (awareness) has been the driving force for the Chinese government's growing concern about the SCS (attitude) and thus leading to its implementing a series of specific policies in the SCS (action).

From the aspect of geostrategic competition, China's growing assertiveness in the SCS can pose a significant/potential threat to Australian security. In Australia's 2009 Defence White Paper, Minister for Defence Joel Fitzgibbon stressed that "the rise of China" is one of the first biggest changes to Australian outlook over the period (Government, Defending Australia in the Asia Pacific Century: Force 2030, 2009). As the Prime Minister, what Kevin Rudd said publicly and privately "gave the impression that he saw China's growing power as a threat" (White, A Middling Power: Why Australia's defence is all at sea, 2012). Especially, when we have seen through history that Chinese presence in Southeast Asia has challenged the stability and security in the region. In case of China's control over the SCS, Australia can hardly find ways to access the maritime trade routes, which may follow by Australia's inability to exploit the maritime economic resources in the SCS. Besides, Australia's presence in Southeast Asia can be impaired in terms of China's territorial sovereignty ambitions. The growing military presence of China in the SCS could destabilize the regional security since it can provoke the strategic imbalance in the Indo-Pacific region. When ASEAN has remained highly dependent on China's economy, Australia's involvement in the SCS can produce two new promising possibilities. The first is to help ASEAN countries lessen their economic dependence on China, and the other is to provide a greater economic diversity for those countries. In the context of ASEAN's searching for a regional balance, Australia would have more chances of actively engaging in Southeast Asia.

\subsection{Australia's Interests in the South China Sea}

Though not having claims in the disputed sea, Australia shares pragmatic and long-term benefits in the SCS. Basically, the interests of Australia can be structured around the following issues: the emerging geostrategic significance of the SCS under Australia's perception; Australia's growing shift "towards Asia" strategy in the 21 st century; Australia's strategic approach towards Asia-Pacific countries, in which Australia's relations with ASEAN and major powers like the U.S. and China are among the most prominent concerns.

First, Australia has deep interests in the SCS, among those trade and security are interconnected. Being one of the major world trade routes, the SCS is a bridge serving to regulate North-South trade flows in the East-Asia region. Indeed, Australia's maritime trade routes with Northeast Asia countries must pass through the SCS. In the context of global trade, ship-borne trade in the SCS has been one of the growing concerns of Australia. Attending the 8th East Asia Summit (EAS) in Brunei Darussalam which was held on 10 October 2013, the Australian Prime Minister Tony Abbott affirmed: "Almost 60 per cent of our trade goes through the South China Sea, so strategic stability is very important" (Kenny, 2013). The stability of the SCS will ensure that Australia's maritime trade presence in the SCS is favorable. Along with the commercial trade routes through the SCS, the safety of the Sea Lines of Communication (SLOCs) has emerged as the very first requirement for Australia's integration into Southeast Asia. Since the end of the Cold War (1991) and notably since the start of the 21st century, the prosperity of Australia and regional security issues have inextricably linked.

Preserving stability, security and development of the Asia-Pacific region has proved to be essential for Australia's national interests. Australia has the benefit of ensuring maritime safety and economic exchanges for its trade routes through the SCS. Regarding the security and defense approach, territorial disputes in the SCS and Chinese military assets are shadowing the regional security; and this instability has posed a direct threat to Australia's presence in the SCS. In light of the shifting balance of power in Southeast Asia, Australia should not adopt an indifferent stance but make vital adjustments to formulate its new defense policy in the Asia-Pacific Century. As the report "Force 30" points out, "Beyond our immediate neighborhood, Australia has an enduring strategic interest in the stability of the wider Asia-Pacific region" (Government, Defending Australia in the Asia Pacific Century: Force 2030, 2009).

Second, the SCS is an important part of Australia's "integration into Asia". From the Second World War (1945) to the early years of the second decade of the 21st century, Australia's perceptions of Asia have captured the country and shaped the way Australia adapts to the times. "Australia's Foreign and Trade Policy White Paper" 
entitled "Advancing the National Interest" which was published in 2003 reflects a strategic thinking in Australia's foreign policy in the 21 st century: "Close engagement with the countries of Asia is an abiding priority in Australian foreign and trade policy. Such engagement will emphasise key strands, including important economic and trade links, valuable diplomatic and security relationships with many countries in Asia, and growing people-to-people links. The Government is committed to working closely with all our Asian partners on the basis of mutual respect and shared interests" (Trade, 2003). From the beginning of the second decade of the 21st century, Australia's engagement with Asia has been the ongoing vision of the Government: "Australia's integration into Asia has been and is contributing to our national prosperity, to our vibrant and diverse society and to our security" (Government, Australia in the Asian Century, 2012).

The tensions in the SCS have a palpable impact on how Australia sees Asia. Australia now recognizes the sharper sense of opportunities and challenges in Asia. Geopolitically, forming comprehensive cooperation with countries in the region would help Australia identify itself as an Asia-Pacific country (Tien, 2012). Australia's gradual recognition of the dynamics of its relationship with the countries of Southeast Asia is the very first requirement for the integrity of Australia. When the maritime security has served as the driving force for greater cooperation among nations, Australia's efforts to play a more vital role in the region formed the basis landscape for the "be part of Asia" strategy (Valencia, 2006). In the wake of an increasingly unstable security in the disputed waters, Australia is responsible for promoting peace and security in the SCS regarding its traditional/leading middle power status. Australia's active evolving engagement with Southeast Asia in the peace-building process will not only provide a good manifestation of its responsible status but also contribute to the new pragmatic foreign policy towards Southeast Asia - one of the most dynamic regions in the world.

Third, the SCS is the "pivot" in Australia's efforts of seeking to advance strategic influence in the Asia-Pacific region. Though situated on the southern margin of the SCS, Australia has its geopolitical movements closely fringed to the SCS. Australia is unique in the scale of its geography: an island, a continent and a nation. The geopolitics of Australia "bears some resemblance to the United States in that sense, albeit without even the friendly, and far from geopolitically troublesome, neighbors to its north and south. Isolated from external threats by water, Australia, like the United States, has the option - and at times displays a propensity - to turn inward, neglecting the sea and the navy. If Canberra can look east into the Pacific or west into the Indian Ocean, it can also look north into the South China Sea or operate outside the perimeter of that contested expanse" (Holmes, 2013). Should Australia wish to be a "true maritime power", Canberra's foreign policy needs a more comprehensive approach basing on the thorough understanding of the vital role of the SCS. The status of a strong maritime power in the future implies that Australia should expand its strategic horizons and settings at sea In other words, Australia's regional security environment is highly vulnerable by the growing tensions and conflicts in the SCS. In that sense, Australia's development should be "towards the SCS" which serves to be more strategic in the foreseeable future. An inward-facing Australia may include the ignorance of the role of the sea and the navy. The shift in the distribution of regional powers in the SCS remains significant and can result in clashes and conflicts over the coming decades. Ensuring peace and security structure in the SCS will ensure that movements in the region will not jeopardize Australia's security and development.

In view of the assessments above, Australia's strategic interests are oriented towards preventing strategic disputes among major powers that can threaten regional stability. On the one hand, Australia appears to benefit from the preventing "the rise" of any country whose ambition may deter Australia's interests. On the other, the Australian government's desire to support the states in neighboring region will be visible only when those neighbors' rise does not place Australia's security under threat (Defence, 1997). Given its geopolitical importance, the SCS has increasingly been one of the foremost concerns of Australia. Ever since the SCS has been shadowed with conflicting claims and strategic competition of major powers, Canberra's security has led to a much more direct concern in the contemporary Southeast Asia and the wider Asia-Pacific than the twentieth century.

\subsection{Australia's Proactive Middle-Power Status in the 21st Century}

Being a middle power requires making tangible contributions and generating goodwill to the security environment on the world stage. Australia's integration into Asia desires the ensuring access to its Asian neighbors. Australia's geographical proximity to Asian countries along with its historical ties provide fundamental opportunities for Australia to access and thereby adapt to the strategic environment in the region. However, the increasingly unstable SCS can be a potential setback for Canberra's interests in Southeast Asia. Through the lenses of middle power activism, new dynamism to Australia's foreign policy must be undertaken both in a theoretical and empirical sense. The rationale behind Australia's middle-power status also comes from the fact that Australia's ability to pursue and achieve specific foreign policy goals is "constrained by great 
powers' interests and consent, and also by the nature or commonalities" (Kaya, 2014) of its diplomatic practice. Hence, maintaining the stability in the SCS proves to be one of the very first concerns of Australia in the Asian century. Australia's active involvement in the SCS serves as the litmus test for Australia's proactive middle-power status in the 21 st century.

From the IR approach, Australia has at least three relational interests in the SCS disputes. The first is Australia-ASEAN traditional relationship. As a dynamic and comprehensive regional institution in Southeast Asia, ASEAN not only plays a coordinating role in many regional security issues but also regulates great powers' intervention to increase its prestige and achieve a resonance of power in Southeast Asia. In addition, ASEAN's reluctant participation in contentious issues can block its consensus on vital security matters. ASEAN's low-profile approach and its different stances on the SCS issue have gradually weakened ASEAN unity and its member states as individual. In the wake of ASEAN's dilemma, Australia's relationship with ASEAN should be geared towards strategic dimensions which include interlocking in political and economic interests and closely linked to Australia's ingenuity and pragmatism. The second is the growing importance of Australia-U.S. relationship. Australia is "one of the United State's oldest and closest allies" that demands Australia to maintain a "strategic posture that supports U.S. interests in Asia and beyond" (White, Australian Strategic Policy, 2005). Traditionally, Australia's alliance with the U.S. has been vital in American alliance networks that recognized Australia's significant role in U.S. pivot/rebalancing policy in the Asia-Pacific. Regarding that tradition, "the United States views its alliance with Australia as an anchor of peace and stability in the Asia-Pacific region and beyond" (House, 2014). Should the U.S. enter a military conflict with China in the SCS, Australia must be prepared to fulfill its obligations to the U.S. The third is Sino-Australia relationships. Now that China has been the leading trading partner of Australia and a growing major factor in the shaping of regional international relations (Wesley, 2013). Given the fact that China has become Australia's "top-ranked merchandise trade partner" (Findlay, 2011), it is wise that Australia find ways to accommodate its policy to "deepening economic dependence upon a rising power" (Reilly, 2012). Australia's shifting threat perceptions of China may provide implications for a strategic approach towards Sino-Australia relationship. Following the rapidly increasing economic power of China in the global geo-economic stage, Australia should make the most of its economic ties with China while not engaging in security side of this relationship.

From the 20th century until now, the idea of a middle power has produced better implications for Australian foreign policy (Ravenhill, 1998). Now that Australia stands at crossroads. Here, this does not imply the taking sides with the U.S. or China but the signpost shows that there goes to another alternative. Should Australia still identify itself as a "traditional middle power", it must seek to take advantage of China's rise to elevate a new international stature. Since the rise of China has implied great power transitions following by the reconfiguration of geostrategic environment for minor and middle powers (Gilley, 2011), Australia should become more ambitious to accommodate its diplomacy and the future role to the growing regional influence of China. However, conventional IR discourses often identify middle powers as "policytakers" rather than "policymakers" (Reeves, 2014). This misconception of middle powers may shape the understanding that middle powers' options are either bandwagoning or balancing against the hegemon or the rising power. Though middle powers' policy options are limited, those powers are not always under the umbrella of "the strong". In terms of foreign policy tradition and long-term interests, middle powers "can shape how the international system works to protect its interests, even in the face of competing interests of a major power' conciliating power" (White, The Defence White Paper and Australia's Future in Asia: Will We Remain a Middle Power?, 2009). Andrew Carr preferred the systemic impact approach, as it "defines middle powers through their ability to alter or affect specific elements of the international system in which they find themselves. This approach defines middle powers through the outcome, rather than the intention, of their actions" (Carr, 2013). In time of Sino-American nascent competition, Australia has a major stake in playing the role of a reconciling power thus contributing to the stability and security in the SCS. The ability of Australia to be self-reliant in Australia-US alliance or pragmatic in Australia-China relations seems to be a direct manifestation of its engagement strategy in the SCS. Australia's engagement in the SCS will not only secure its strategic interests but also ensure its proactive middle-power status in the 21 st century.

\section{Australia's Further Engagement in the South China Sea and Strategic Implications for Australia-Vietnam Relations}

Radically, contemporary challenges and opportunities in Southeast Asia serve as the primary motive that leads Australia to sharpening its foreign policy. "In matters of security, most states are more concerned with events in nearby states than in those that are far away. Australia, for example, can do little to enhance global security, while it may do much to enhance regional security. For the last 30 years Australian governments have tended to 
define South-East Asia and the South Pacific as Australia's region for security matters" (Firth, 2005). As a response to Southeast Asia's changing security environment, Australia has tried to pursue cooperation with regional states on regional concerns including the territorial disputes. In an effort to strengthen Australia-ASEAN relations, Australia considers Vietnam as a peaceful and positive bridge that helps Australia promote its policy of "integration into Asia". From 2009 until now, Australia and Vietnam have increasingly shared the traditional and non-traditional security concerns in the SCS. With regard to those threats, both countries have strengthened strategic security commitments by providing diplomatic support for freedom of navigation and peaceful settlements of disputes in the SCS. On the one hand, this reflects Australia's perception of the significant importance of the SCS and, on the other, affirms Australia's growing influence in the region.

In terms of Australia-Vietnam relations, the 2013 major study of Australian defence maritime security (re) engagement from Australian Strategic Policy Institute (ASPI) revealed that: "From an Australian point of view, we should be cautious about being involved in exercises with Vietnam if they involve operations in the South China Sea" (Sam Bateman, 2013). Moreover, the two countries' defense cooperation does not yet include Australia's provision of facilities to strengthen Vietnam's maritime security. Essentially, Australia has managed to remain "neutral", avoiding getting involved in territorial disputes in the SCS. As Australia's economic relationship with China has blossomed, Australia is putting emphasis on a so-called pragmatic relationship with Vietnam. Behind that is Australia - "the developed world's most China-reliant economy" (Health, 2016) maintained the prudent and conservative approach towards the SCS. In this larger sense, Australia-Vietnam relations relate to the strategic trajectory of Australia's regional policy in the Asia-Pacific. Despite the fact that Australia-Vietnam cooperation on the SCS issue has progressed with closer economic, political and security ties, there seems much to be done to ensure a strategic stability in the SCS issue and beyond. While some great powers seek to find themselves as balancing external powers - outside the string of maritime disputes in the SCS, Australia should be more cautious not to undermine its influence in the region. In order to be highly respected as the true active middle power, Australia has more responsibility to be a major architect in the maritime security mechanism in the SCS.

Economically, politically and strategically, Australia can "promote the notion of an operational and strategic level agreement to cover issues such as safety zones around disputed features, restrictions on particular types of operation in particular areas, such as submarine 'no go' areas, hot lines, operational transparency, and prior notices of operations" (Bateman, 2015). Constructive and peaceful resolutions to manage the SCS disputes are to cultivate Australia's relations with Vietnam while maintaining both active interactions and good relationship with China. Given that efforts to reduce tension in the SCS seems little likelihood of successful in the very near future, Australia and Vietnam should cooperate to enhance regional cooperation by developing maritime confidence-building measures to reduce tension in the SCS. Such maritime confidence-building measures consist of both direct and indirect activities with focus on building real-time communication channel, promoting transparency and confidence among nations (Rory Medcalf, 2011). As discussed, "Australian policy at the least must include proactive and honest engagement with all claimant nations, even where that is resented, in multiple bilateral and multilateral forums in order to continually seek avenues that might lead to eventual resolution" (Ghee, 2016). The recent developments in Australia-Vietnam relationship is the presence of a mature convergence of outlook in preserving security in the SCS. The Comprehensive Partnership which was formalized in 2009 laid good foundation for both countries to work together to discuss cooperative schemes and possible procedures for managing potential conflicts in the SCS. The joint statement on Comprehensive Partnership aimed at promoting dialogues and cooperation in the maritime domain that served as a preventive diplomatic measure to ensure a state of détente in the SCS. On behalf of shared interests and common policy goals, Australia and Vietnam have sought to seize the "golden opportunity" provided by the Comprehensive Partnership to raise bilateral relations to a considerable breadth and depth, thus intensifying political influence in the region. While the prevailing argument has been central that Australia is a traditional middle power, it is noteworthy to mention the stature of Vietnam as a potential middle power.

For years, Vietnam's foreign policy has envisioned itself as a potential middle power. Within Southeast Asia, Vietnam's young population and its successful economic transformation gain reputation for a dynamic actor in the regional stage. While the geostrategic position of Vietnam enables this country to take advantages of both continental and maritime settings, Vietnam has attempted to become a key player in the region. Singapore's founding Prime Minister Lee Kuan Yew declared in 1979 "there is no combination of forces in Southeast Asia that can stop the Vietnamese on the mainland of Asia" (Porter, 1979). Since the adoption of Doi Moi (renovation) in December 1986, Vietnam's foreign policy has reflected the long-term of regional and international integration in which economic reforms and the new political thinking favored as the positive contributions. The ability of 
Vietnam to stay neutral and seek interests from hegemonic powers shaped its increasing flexible foreign policy. Vietnam's working towards greater strategic interdependence among giants in the region has been highly evaluated (Ikenberry, 2002). Other advocate is the strategy of Vietnam to lean on ASEAN to promote its regional integration. Vietnam's "ASEAN-based integration policy in economic and politico-security dimensions" (Nguyen, 2015) has followed by Hanoi's addressing ASEAN as a foreign policy leverage from which Vietnam can pursue a strategy of balancing its interests and influence among great powers (great-power enmeshment).

Since the multidirectional foreign policy of Vietnam has continued to experience remarkable achievements, Australian participation in the SCS has not only helped Australia achieve strategic goals but also turned out to ensure a strategic chance for Australia to promote Australia-Vietnam relations. Instead of pursuing reticent views on the SCS issue, Australia has committed to strengthening cooperation with Vietnam to ensure maritime security in the region. Since Australia and Vietnam strongly share the same concerns about the peace and security in the SCS, both countries should coordinate to promote the observance of norms and rules in the region. When Australia finds it hard to be neutral in the SCS dispute, Canberra can work to join hands with Vietnam to strengthen non-traditional security cooperation. Those strenuous efforts will pave the way for further cooperation such as information exchange, military cooperation or joint military drills with Vietnam (bilateral) and other Southeast Asian countries (multilateral). Then, institutionalized self-restraint mechanism organizing upon legal and political institutions can serve as basic features for regional constitutional order. With this constitutional landscape, the attempt of hegemon or great powers seems to be more predictable and less threatening in some cases (Vu, 2017). Given that the 2015 Declaration on Enhancing the Australia-Vietnam Comprehensive Partnership builds upon the 2009 Australia-Vietnam Comprehensive Partnership, Australia-Vietnam defence and security cooperation has witnessed vital achievements. The upshot, is that, this convergence of interests between Australia and Vietnam in the political and security spheres confirms the potential for a positive and peaceful relationship.

When the escalation of tensions in the SCS has been primed to continue, the future dynamics of Asia seems to be determined by the rising/reviving of Australia as the middle power. In terms of foreign policy, both Australia and Vietnam have showed a tendency of realism towards "the changing power dynamics and security issues" (Tan, 2013). On that basic, both countries fit well with the need to recognize the importance of international norms and peaceful means to manage tensions in the SCS. Given security concerns over the SCS, it is encouraging that there has been highly perceived of cost and risks in the perspectives of leaders from Australia and Vietnam. Through regular political dialogue and economic interaction, Australian leaders recognize benefits of economic cooperation while Vietnamese leaders are highly concerned about the lynchpin of political legitimacy. Both leaders' cost-benefit calculations are vital for regional security cooperation.

Australia for a long time has maintained a so-called "conservative" approach towards the SCS issue but after 2009 Canberra has become more vocal in expressing concerns about the rising tensions in disputed waters. First, Australia shares common views with Vietnam; then, Australia has been engaging in discussions with Vietnam regarding the maritime security and the growing assertiveness of China over territorial disputes. Australia has maintained a tough stance towards actions that can threaten the stability and prosperity of Southeast Asia region and beyond. On that basic, Australia goes on to promote practical cooperation with Vietnam in terms of the SCS issue. The two governments, both of which wish to avoid the prospect of "war on water", have regularly conducted diplomatic-security-defense dialogue on regional security with the attention of further enhancing mutual trust. At the locus of contemporary challenges, the two countries find themselves confronting salient issues and thus sharing convergent maritime security views and the need to foster strategic understanding and mutual respect. It should be noted that Australia's strengthening ties with Vietnam and increasing its presence in the SCS have received no offense response from great powers such as the U.S., Japan, India, and Russia. This attitude is in deep contrast with the actions increased by China's military presence in the SCS. Under unfavorable regional circumstances, Australia's moderate approach was as worth evaluating as welcoming by Vietnam as well as regional countries (not including China). This will provide favorable conditions for Australia to pursue strategic interests through security commitments and sustainable presence in the SCS to promote peaceful solutions recognized by the principles of international law. The efforts of Australia in promoting security cooperation in the SCS reflect that Canberra has been playing a more active role in the region while not getting involved in the SCS disputes.

\section{Concluding Remarks}

The prospect theory approach provides a theoretical framework to explain the engagement of country in international disputes, which has a focus on regional "flashpoints". In the case of the SCS, Australia's strategic benefits in Southeast Asia and the wider Asia-Pacific region have served as the incentive that directly defines its 
involvement in the contested waters. Meanwhile, Australia is more sensitive to losses than to gains, thus leading to its risk-acceptant behavior in the SCS. A good starting point for Australia to ensure peace and security and, to a lesser extent, prosperity in Southeast Asia is to get involved in the region. In this scenario, Australia's policy independence is determined only by accommodating its creative middle power status with supportive contributions toward the enhancing security and prosperity in Southeast Asia. Asserting Australia's future wellbeing can be encouraged by its seeking the honest broker role in the SCS disputes.

Of significant note is the vital role of Vietnam in Australia's "to be part of Asia" vision. In the practice of promoting Southeast Asia security, Australia soon recognizes that Vietnam's stance toward regional security and its legal preference to solve the SCS issue has been in line with Australia's orientation. Australia-Vietnam comprehensive partnership (since 2009) is a milestone that helps enhance strategic trust and advance maritime diplomacy. While a number of countries in Asia-Pacific region have been in favor of a "risk-averse" approach toward the SCS issue and in some cases have conducted little cooperation with Vietnam relating to the SCS issue, the pragmatic and inoffensive approach of Australia will shape long-term benefits of Australia in the regional hierarchy. Australia's support for international binding and regional norms is likely to be further developed by launching a diplomatic and economic campaign to synchronize its creative middle power status with its empirical settings. There is much prospect of Australia upholding a kind of "soft-alliance" mechanism with benign powers in the East Asia. Among those powers, Vietnam has been highly evaluated by Australian Government. In the early stages, both countries can institutionalize their cooperation by promoting bilateral relations in multilateral regional institutions. Convergent interests remain a dynamic force for "core values" around soft-alliance. Later, Australia and Vietnam are required to work together to further engage benign powers (India, Japan, Korea, Indonesia, Singapore, Malaysia...) into the regional "concern of powers". As regional (and even some external) benign powers enjoy cooperative relations characterized by practical collaborative measures, the regional security network is more likely to be enforced. For the time being, Australia remains prone to feel emboldened by Southeast Asian countries.

Regarding the SCS issue, Australia-Vietnam relations reflect the nature of "equality" - peaceful and mutual sharing. For Australia, it is the strategy of promoting ties with ASEAN and at the same time relieving economic pressure from China. For Vietnam, what matters is the need to promote multilateral balance in relations with great powers. Following extensive achievements through proactive international integration, Vietnam continues to be an important factor that Australia must take into account when conducting foreign relations in Asia-Pacific. Following the achievements in the past, potential exists for stronger development in Australia-Vietnam relations. There is much evidence that both countries are prepared for the changes in the dynamics of security in the SCS. The tightening of Australia-Vietnam relations is well suited to the strategic interests of both countries in Southeast Asia. In the context of regional power transition, Australia-Vietnam's cooperation on managing the SCS issue is a good demonstration for a trans-regional comprehensive partnership. The advent of Australia-Vietnam cooperative relations regarding the SCS issue in terms of "institutional engagement" would contribute to the shaping of regional order.

\section{References}

哎梦哦彼咯. (2015). 2011-2012 中国周边安全形势分析(鄙视某某人) 第1 页. Retrieved June 7, 2017, from http://www.uuwenku.com/wenku/list-54/article/p-1533662.html

Barbara Farnham. (1994). Avoiding Losses/Taking Risks: Prospect Theory and International Conflict. MI: The University of Michigan Press. doi:10.2307/40203797

Barberis, N. C. (2013). Thirty Years of Prospect Theory in Economics: A Review and Assessment. Journal of Economic Perspectives, 27(1), 173-92. doi:10.1257/jep.27.1.173

Bateman, S. (2015, May 28). What are Australia's interests in the South China Sea? Retrieved June 7, 2017, from $\begin{array}{llll}\text { Australian Strategic Policy } & \text { Institute }\end{array}$ http://www.aspistrategist.org.au/what-are-australias-interests-in-the-south-china-sea/

Berejekian, J. (1997). The Gains Debate: Framing State Choice. American Political Science Review, 91(4), 789-805. doi:10.2307/2952164

Brzezinski, Z. (2004). The Choice: Global Domination or Global Leadership. New York: Basic Books.

Carr, A. (2013). Is Australia a Middle Power: The Systemic Impact approach. Australian Journal of International Affairs, 68(1), 79. doi:10.1080/10357718.2013.840264

Daniel Kahneman, J. K. (1990). Experimental tests of the endowment effect and the Coase theorem. Journal of Political Economy, 98(6), 1325-48. doi:10.1086/261737 
Defence, D. O. (1997). Australia's Strategic Policy. Defence Publishing and Visual Communications.

Findlay, C. (2011). Australia-China Economic Relations. In J. G. Song, Rising China: Global Challenges and Opportunities (p. 181). The Australian National University Press.

Firth, S. (2005). Australian in International Politics: An introduction to Australian foreign policy. Sydney: Southwood Press.

Full text of Hu Jintao's Report at the 18th Party Congress. (2012, November 17). Retrieved June 7, 2017, from Xinhua: http://news.xinhuanet.com/english/special/18cpcnc/2012-11/17/c_131981259.htm

Ghee, G. C. (2016). Policy Options for Australia to Support Stabilisation and Resolution of Maritime Disputes in the South China Sea. Indo-Pacific Strategic Papers, 19.

Gilley, B. (2011). Middle Powers during Great Power Transitions: China's Rise and the Future of Canada-US Relations. International Journal, 66(2), 245-264. doi:10.1177/002070201106600202

Government, A. (2009). Defending Australia in the Asia Pacific Century: Force 2030. Commonwealth of Australia.

Government, A. (2009). Defending Australia in the Asia Pacific Century: Force 2030. Commonwealth of Australia.

Government, A. (2012). Australia in the Asian Century. Commonwealth of Australia.

He, K. (2014). Prospect Theory and China's Crisis Behaviour under Hu Jintao. The RSIS Working Paper, $284,7$.

Health, M. (2016, March 29). Most China-Dependent Economy Isn't So Keen on Chinese Money. Retrieved June 5, 2017, from https://www.bloomberg.com/news/articles/2016-03-28/the-most-china-dependent-economy -isn-t-so-keen-on-chinese-money

Holmes, J. R. (2013, October 9). The Geopolitics of Australia. Retrieved May 8, 2017, from The Diplomat: $\mathrm{http} / /$ thediplomat.com/2013/10/the-geopolitics-of-australia/

House, T. W. (2014, June 12). FACT SHEET: The United States and Australia: An Alliance for the Future. Retrieved May 14, 2017, from Office of the Press Secretary: https://obamawhitehouse.archives.gov/ the-press-office/2014/06/12/fact-sheet-united-states-and-au

Ikenberry, G. J. (2002). Between Balance of Power and Community: The Future of Multilateral Security Cooperation in the Asia Pacific. International Relations of the Asia-Pacific, 2, 69-94. doi:10.1093/irap/2.1.69

Kaya, G. B. (2014). Testing the creativity of Kevin Rudd's middle power diplomacy: EU-Australia partnership framework versus the Asia-Pacific community. International Relations of the Asia-Pacific, 14(2), 239-269. doi:10.1093/irap/lct025

Kenny, M. (2013, October 10). Tony Abbott warns of conflict risk in South China Sea. Retrieved May 5, 2017, from The Sydney Morning Herald: http://www.smh.com.au/federal-politics/political-news/tony-abbott -warns-of-conflict-risk-in-south-china-sea-20131010-2vb

Leonie Huddy, D. O. (2013). The Oxford Handbook of Political Psychology. Oxford University Press. doi:10.1093/oxfordhb/9780199760107.001.0001

Levy, J. S. (1992). An Introduction to Prospect Theory. Political Psychology, 13(2), 171-86.

Milton Friedman. (1957). The Methodology of Positive Rationality. In M. Friedman, Essays in Positive Economics (pp. 3-43). Chicago: University of Chicago Press.

Nguyen, Q. (2015). Vietnam's ASEAN Strategic Objectives since the 1986 Doi Moi Reform. Scholars' Press.

Porter, A. (1979, February 6). Transcript of an interview with the Prime Minister, Mr. Lee Kuan Yew. Retrieved June 5, 2017, from http://www.nas.gov.sg/archivesonline/data/pdfdoc/lky19790206.pdf

Ravenhill, J. (1998). Cycles of Middle Power Activism: Constraint and Choice in Australian and Canadian Foreign Policy. Australian Journal of International Affairs, 52(3), 317-318. https://doi.org/10.1080/103577 19808445259

Reeves, J. M. (2014). Locating Middle Powers in International Relations Theory and Power Transitions. In B. G. O'Neil, Middle Powers and the Rise of China (p. 23). Georgetown University Press.

Reilly, J. (2012). Counting on China? Australia's Strategic Response to Economic Interdependence. Chinese Journal of International Politics, 5(4), 369-394. https://doi.org/10.1093/cjip/pos016 
Rory Medcalf, R. H. (2011). Crisis and Confidence: major powers and maritime security in Indo-Pacific Asia. Sydney: Lowy Institute for International Policy.

Sam Bateman, A. B. (2013). Terms of engagement: Australia's regional defence diplomacy. Australian Strategic Policy Institute.

Taliaferro, J. W. (2004). Balancing Risks: Great Power Intervention in the Periphery. Cornell University Press. doi:10.1177/0010414004273208

Tan, A. T. (2013). East and South-East Asia: International Relations and Security Perspectives. Routlegde.

Thaler, R. H. (1999). The End of Behavioral Finance. Financial Analysts Journal, 55(6), 15. doi:10.2469/ faj.v55.n6.2310

Tien, T. N. (2012). Asia in Australia's foreign policy: from history to present. Journal of Social Sciences and Humanities, 53, 22.

Trade, T. A. (2003). Advancing the National Interest. Commonwealth of Australia.

Truong, N. N. (2014). On the South China Sea issue. Hanoi, Vietnam: National Politics Publishing House.

Tversky, D. K. (1974). Judgment under Uncertainty: Heuristics and Biases. Science, 185(4157), 1124-31. https://doi.org/10.2307/3151689

Tversky, D. K. (1979). Prospect Theory: An Analysis of Decision under Risk. Econometrica, 47(2), 289. https://doi.org/10.2307/1914185

Tversky, D. K. (1984). Choices, Values, and Frames. American Psychologist, 39(4), 342. https://doi.org/10.1037/ 0003-066X.39.4.341

Valencia, M. (2006). The Proliferation Security Initiative: Making Waves in Asia. New York: Routledge.

Vu, T.-M. (2017). The Logic of Strategic Restrain and Prospects for Joint Development in the South China Sea. In A. G. Strašáková, Unresolved Border, Land and Maritime Disputes in Southeast Asia Bi-and Multilateral Conflict Resolution Approaches and ASEAN's Centrality (p. 235). Leiden: Brill.

Wesley, M. (2013). Australia's interests in the South China Sea. In L. B. Roberts, The South China Sea and Australia's Regional Security Environment (pp. 45-49). Australian National University.

White, H. (2005). Australian Strategic Policy. In A. J. Wills, Military Modernization in an Era of Uncertainty, Strategic Asia 2005-06 (p. 305). The National Bureau of Asian Research.

White, H. (2009, May 21). The Defence White Paper and Australia's Future in Asia: Will We Remain a Middle Power? Retrieved June 6, 2017, from Australian National University Podcast Public Lecture.

White, H. (2012, September). A Middling Power: Why Australia's defence is all at sea. Retrieved February 25, 2017, from https://www.themonthly.com.au/issue/2012/september/1346903463/hugh-white/middling -power

\section{Copyrights}

Copyright for this article is retained by the author(s), with first publication rights granted to the journal.

This is an open-access article distributed under the terms and conditions of the Creative Commons Attribution license (http://creativecommons.org/licenses/by/4.0/). 